Available online at: https://jurnal.unej.ac.id/index.php/JLC
LEARNING COMMUNITY
Jurnal Pendidikan Luar Sekolah, $4(1), 2020,58-61$

\title{
Hubungan Program Life Skill Berbasis Potensi Lokal Dengan Peningkatan Ekonomi Masyarakat Di Desa Lombok Kulon Kecamatan Wonosari Kabupaten Bondowoso
}

\author{
Mohammad Anwar Razzaki ${ }^{1}$, AT. Hendrawijaya ${ }^{1}$, Lutfi Ariefianto ${ }^{1}$ \\ ${ }^{1}$ Pendidikan Luar Sekolah, Universitas Jember. Jl. Kalimantan No. 37, Tegal Boto, Jember 62811, Indonesia \\ anwarrazzaki@gmail.com, lutfipls.fkip@unej.ac.id
}

\begin{abstract}
Abstrak
Pemberdayaan masyarakat sangat dibutuhkan untuk peningkatan ekonomi masyarakat, untuk mengurangi angka kemiskinan dan pengangguran. Salah satunya kerajinan yang ada di Desa Lombok Kulon dan diprakarsai oleh desa wisata. Berdasarkan latar belakang masalah dan rumusan masalah dalam penelitian ini adalah adakah hubungan program life skill berbasis potensi lokal dengan peningkatan ekonomi masyarakat di desa Lombok Kulon Kecamatan Wonosari Kabupaten Bondowoso. Jenis penelitian yang digunakan dalam penelitian ini adalah penelitian korelasional dengan pendekatan kuantitatif. Teknik pengumpulan data yang digunakan peneliti yakni melalui observasi dan dokumentasi. Teknik analisis data yang digunakan peneliti yakni dengan menggunakan rumus korelasi tata jenjang yang dibantu dengan menggunakan alat bantu SPSS seri 24. Hasil penelitian dapat disimpulkan bahwa terdapat hubungan antara program life skill berbasis potensi lokal dengan peningkatan ekonomi masyarakat di Desa Lombok Kulon.
\end{abstract}

Kata Kunci: Pemberdayaan Masyarakat, Life Skill, Berbasis Potensi Lokal, Peningkatan Ekonomi

\section{The Entrepreneurship Program on the Independence of Package C Learning Group}

\begin{abstract}
Community empowerment is needed to improve the community's economy, to reduce poverty and unemployment. One of them is a craft in the village of Lombok Kulon and was initiated by a tourist village. Based on the background of the problem and the formulation of the problem in this study is is there a relationship between life skills programs based on local potential and economic improvement of the community in Lombok Kulon village, Wonosari District, Bondowoso Regency. The type of research used in this study is correlational research with a quantitative approach. Data collection techniques used by researchers are through observation and documentation. The data analysis technique used by researchers is by using a hierarchical correlation formula that is assisted by using SPSS 24 series tools. The results of the study can be concluded that there is a relationship between life skills programs based on local potential and economic improvement of the community in Lombok Kulon Village.
\end{abstract}

Keywords: Community Empowerment, Life Skill, Based on Local Potential, Economic Improvement 


\title{
Learning Community: Jurnal Pendidikan Luar Sekolah, 4 (1), Maret 2020 - 59
}

\author{
M. Anwar Razzaki
}

\section{PENDAHULUAN}

Strategi pembangunan di Indonesia dimulai dengan peningkatan pemerataan pembangunan di daerah pedesaan. Masyarakat sebagai subyek pembangunan harus memiliki kesadaran untuk memperbaiki kehidupannya menjadi lebih baik. Program pembangunan yang dilakukan diharapkan mampu membantu menurunkan angka kemiskinan dan pengangguran. Salah satu program pembangunan yaitu pemberdayaan masyarakat, proses pemberdayaan yang melahirkan masyarakat yang memiliki sifat seperti yang diharapkan harus dilakukan secara berkesinambungan dengan mengoptimalkan partisipasi masyarakat secara bertanggung jawab.

Salah satu program pembangunan yaitu pemberdayaan masyarakat, proses pemberdayaan yang melahirkan masyarakat yang memiliki sifat seperti yang diharapkan harus dilakukan secara berkesinambungan dengan mengoptimalkan partisipasi masyarakat secara bertanggung jawab. Kemiskinan dapat diselesaikan dengan program pemberdayaan melalui kegiatan life skill. Salah satunya kerajinan yang ada di desa Lombok Kulon dan diprakarsai oleh desa wisata. di desa Lombok Kuon masyarakat setempat kurang memiliki kreativitas dan inovasi dalam pemanaatan potensi lokal. Hal ini bertujuan untuk membuat peluang memperoleh penghasilan tambahan bagi masyarakat dan untuk mendukung program pemerintah dalam menumbuh kembangkan industri kecil demi perbaikan ekonomi rakyat. Pendidikan kecakapan hidup (life skill eduation) adalah pendidikan yang memberikan bekal keterampilan yang praktis, terpakai, terkait dengan kebutuhan pasar kerja, peluang usaha dan potensi ekonomi industri yang ada di masyarakat (Anwar, 2004).

Kerajinan boneka organik dilakukan untuk meningkatkan ekonomi masyarakat. Kerajinan ini sebenarnya adalah salah satu solusi untuk mengurangi angka garis kemiskinan dan pengangguran di desa Lombok Kulon. Program pembangunan yang dilakukan melalui peningkatan kualitas dalam industri kerajinan boneka organik memberikan dampak bagi masyarakat, khususnya pada perempuan yang dapat membantu perekonomian pada keluarganya.

Pengrajin boneka organik di desa Lombok Kulon sebagian besar adalah perempuan dan sebagian kecil adalah lakilaki. Hal ini menunjukkan bahwa di desa Lombok Kulon seorang perempuan sangatlah berperan penting dalam memenuhi kebutuhan ekonomi. Pembangunan ekonomi dalam jangka Panjang akan membawa perubahan mendasar dalam struktur ekonomi, semakin tinggi laju pertumbuhan ekonomi yang diikuti dengan semakin cepat proses peningkatan pendapatan per kapita masyarakat maka semakin cepat pulaperubahan struktur ekonomi di suatu Negara. (Tambunan, 2002)

\section{METODE}

Penelitian ini merupakan jenis penelitian korelasional dengan pendekatan kuantitatif. Penelitian ini dilakukan selama 6 bulan yaitu mulai bulan September 2018 - Maret 2019 di Desa Lombok Kulon tempat kerajinan boneka organik Kabupaten Bondowoso sebagai daerah yang dipilih untuk tempat penelitian dengan menggunakan teknik purposive area. Sedangkan untuk pengumpulan datanya menggunakan kuesioner atau angket dan dokumentasi. Pengumpulan data di atas selanjutnya dibuktikan melalui pengisian angket dengan menggunakan checklist kepada 24 subjek penelitian yaitu Desa Lombok Kulon yang mengikuti program life skill. Dalam penelitian ini penentuan subjek penelitian menggunakan teknik populasi. Dalam pengisisan angket menggunakan checklist terdapat 24 butir pernyataan selanjutnya dilakukan editing, coding, scoring, dan tabulating. Jika keseluruhan item pernyataan tersebut sudah terisi, maka akan dilakukan analisis data lebih lanjut dengan menggunakan rumus korelasi tata jenjang.

\section{HASIL DAN PEMBAHASAN}

Desa Lombok Kulon merupakan salah satu wilayah di Kabupaten Bondowoso. Desa Lombok Kulon terbagi menjadi 5 (lima) dusun yaitu Dusun Krajan, Dusun Krajan 1, Dusun Pasar, Dusun Wonosroyo Timur dan Dusun Wonosroyo Barat. Ketinggian tempat wilayah ini adalah 
Learning Community: Jurnal Pendidikan Luar Sekolah, 4 (1), Maret 2020 - 60

\section{Anwar Razzaki}

0-230 mdpl. Curah hujan di Desa Lombok Kulon sebesar 6,475 mm dengan jumlah bulan hujan antara 6 sampai 8 bulan per tahun. Luas lahan persawahan di Desa Lombok Kulon adalah seluas $224 \mathrm{Ha}$, luas tegalan tanaman tebu seluas $60 \mathrm{Ha}$, luas lahan pekarangan produktif seluas $27,5 \mathrm{Ha}$ dan terdapat sungai sepanjang $4 \mathrm{Km}$. Sedangkan luas lahan yang begitu luas serta sungai yang tersedia sangat mendukung masyarakat di Desa Lombok Kulon untuk berusaha di bidang pertanian. Beberapa tanaman dibudidayakan dan salah satunya adalah pisang dan padi, dimana saat ini padi tidak hanya dibudidayakan secara konvensional akan tetapi juga secara organik. Saat ini Desa Lombok Kulon telah menjadi desa wisata organik yang dibina langsung oleh Bapak Drs. H. Amin Said Husni (Bupati Bondowoso), Bapak H. Ahmad Dofir, dan Bapak Adi Sumaryadi S.E. Wilayah ini ratarata masyarakatnya sebagian besar bekerja sebagai petani. Hal ini terlihat dalam Profil Desa Lombok Kulon Tahun 2015, yang diketahui jumlah petani sebesar 326 orang atau 6,97 \% dari total penduduk dan jumlah buruh tani sebesar 993 orang atau 21,25 \% dari total penduduk.

Hasil penelitian dibuktikan melalui proses analisis data menggunakan rumus korelasi tata jenjang pada hasil pengisian angket berupa checklist yang telah dilakukan. Adapun hasil perhitungan yang diperoleh menunjukkan nilai rhitung sebesar 0,784. Nilai tersebut lebih besar dari rtabel sebesar 0,409 (dengan $\mathrm{N}=24$ pada taraf kepercayaan 95\%). Dari nilai tersebut diperjelas kembali melalui hasil analisis data lebih lanjut terhadap masing-masing indikator yaitu sebagai berikut: hubungan antara keterampilan dengan peningkatan ekonomi sebesar 0,823 dengan kategori sangat tinggi. Hal ini menunjukkan bahwa, keterampilan memiliki hubungan dengan peningkatan ekonomi di Desa Lombok Kulon Kabupaten Bondowoso. Adapun hubungan antara pengetahuan dengan peningkatan ekonomi sebesar 0,744 dengan kategori tinggi. Hal ini menunjukkan bahwa, pengetahuan memiliki hubungan dengan peningkatan ekonomi di Desa Lombok Kulon Kabupaten Bondowoso. Dengan demikian dapat disimpulkan bahwa ada hubungan antara program life skill berbasis potensi lokal dengan peningkatan ekonomi masyarakat.

Berdasarkan hasil penelitian yang telah dilakukan maka dapat diketahui bahwa ada hubungan program life skill berbasis potensi lokal dengan peningkatan ekonomi masyarakat Desa Lombok Kulon Kabupaten Bondowoso. Hal ini diperoleh dari data yang telah diolah dan dianalisis lebih lanjut, sehingga secara garis besar penelitian ini menunjukkan adanya hubungan tergolong tinggi antara variabel $\mathrm{X}$ dan variabel $\mathrm{Y}$. Selanjutnya untuk hasil perhitungan variabel $\mathrm{X}$ (program life skill berbasis potensi lokal) dan variabel $Y$ (peningkatan ekonomi), diperoleh rhitung sebesar 0,784 (dengan $\mathrm{N}=24$ dan taraf kepercayaan 95\%), sehingga dapat disimpulkan bahwa Ha diterima dan Ho ditolak. Hasil temuan dilapangan ini, menunjukkan fakta bahwa program life skill berbasis potensi lokal memiliki pengaruh tinggi dengan peningkatan ekonomi masyarakat. Guna memperjelas hasil yang diperoleh dilapangan, maka akan dijelaskan hubungan pada setiap indikator dalam penelitian berikut ini :

Berdasarkan penyajian dan interpretasi data, pada indikator pertama yakni keterampilan, dapat diketahui bahwa besar hubungan antara keterampilan terhadap peningkatan ekonomi, didapatkan hubungan sebesar 0,823 dengan kategori sangat tinggi. Hal ini menunjukkan bahwa terdapat hubungan yang sangat tinggi antara keterampilan dengan peningkatan ekonomi masyarakat di Desa Lombok Kulon Kecamatan Wonosari Kabupaten Bondowoso.

Hasil temuan ini sesuai dengan pendapat para ahli bahwa keterampilan adalah kemampuan untuk menggunakan akal, fikiran dan ide dan kreatifitas dalam mengerjakan, mengubah ataupun membuat sesuatu menjadi lebih bermakna sehingga menghasilkan sebuah nilai dari hasil pekerjaan tersebut. Maka dalam meningkatkan perekonomian masyarakat yang lebih berdaya, masyarakat harus memiliki kecakapan atau keterampilan hidup dengan memanfaatkan potensi lokal sekitar. (Suprapto, 2009)

Sedangkan pada indikator kedua yakni pengetahuan. Berdasarkan penyajian dan interpretasi data, dapat diketahui bahwa besar hubungan antara Pengetahuan 


\section{Learning Community: Jurnal Pendidikan Luar Sekolah, 4 (1), Maret 2020 - 61 M. Anwar Razzaki}

terhadap peningkatan ekonomi, didapatkan hubungan sebesar 0,744 kategori tinggi. Hal ini menunjukkan bahwa terdapat hubungan yang tinggi antara pengetahuan dengan peningkatan ekonomi masyarakat di Desa Lombok Kulon Kecamatan Wonosari Kabupaten Bondowoso.

Hasil temuan ini sesuai dengan pendapat ahli bahwa pengetahuan merupakan hasil dari tahu dan terjadi setelah orang melakukan penginderaan terhadap objek tertentu, serta ada beberapa faktor yang mempengaruhi pengetahuan antara lain, (a) pendidikan, (b) informasi, (c) sosial budaya dan ekonomi, (e) lingkungan, (f) pengalaman, dan (g) usia. Sehingga dalam hal ini memberikan pengetahuan kepada masyarakat dapat menjadikan masyarakat yang produktif, karena di era zaman sekarang masyarakat dituntut kreatif untuk dapat memenuhi kebutuhan hidup seharihari. (Suci, 2006)

\section{SIMPULAN}

Kesimpulan dari penelitian ini yaitu hubungan antara program life skill berbasis potensi lokal dengan peningkatan ekonomi masyarakat di Desa Lombok Kulon Kecamatan Wonosari Kabupaten Bondowoso. Hal ini berati Ha yang berbunyi ada hubungan antara dampak program life skill berbasis potensi lokal dengan peningkatan ekonomi masyarakat di Desa Lombok Kulon Kecamatan Wonosari Kabupaten Bondowoso diterima. Adapun Ho yang berbunyi tidak ada hubungan antara dampak program life skill berbasis potensi lokal dengan peningkatan ekonomi masyarakat di Desa Lombok Kulon Kecamatan Wonosari Kabupaten Bondowoso ditolak. Berdasarkan kesimpulan di atas, adapun saran bagi Pemerintah daerah Kabupaten Bondowoso agar dapat mengadakan program-program yang dapat meningkatkan ekonomi masyarakat. serta dapat menindak lanjuti program yang telah diadakan. Sedangkan saran bagi masyarakat Desa Lombok Kulon agar dapat meningkatkan kreatifitasnya untuk dapat menambah pendapatan ekonomi keluarga.

\section{DAFTAR PUSTAKA}

Anwar. 2004. Pendidikan Kecakapan Hidup (Life Skills Education) Konsep dan Aplikasi. Bandung: CV Alfabeta.

Tambunan, Tulus T.H, 2002. Transformasi Ekonomi di Indonesia: Teori dan Penemuan Empiris. Jakarta: Salemba Empat.

Suprapto, T. 2009. Pengantar Teori dan Manajemen Komunikasi. Yogyakarta: MedPress.

Suci. 2016. Pengetahuan Mahasiswa Universitas Widyatama Tentang Sampah Berpengaruh Terhadap Keputusan Mahasiswa Untuk Membuang Sampah Pada Tempatnya. Skripsi. Bandung: Universitas Widyatama. 